\title{
Archaeologia
}

http://journals.cambridge.org/ACH

Additional services for Archaeologia:

Email alerts: Click here

Subscriptions: Click here

Commercial reprints: Click here

Terms of use : $\underline{\text { Click here }}$

\section{Political Poems of the reigns of Henry VI. and Edward IV., communicated by Sir Frederic Madden, K.H., in a Letter to John Gage Rokewode, Esq. Director S.A.}

\section{Frederic Madden}

Archaeologia / Volume 29 / Issue 02 / January 1842, pp 318 - 347

DOI: 10.1017/S0261340900002125, Published online: 12 June 2012

Link to this article: http://journals.cambridge.org/abstract_S0261340900002125

How to cite this article:

Frederic Madden (1842). XXV. Political Poems of the reigns of Henry VI. and Edward IV., communicated by Sir Frederic Madden, K.H., in a Letter to John Gage Rokewode, Esq. Director S.A.. Archaeologia, 29, pp 318-347 doi:10.1017/S0261340900002125

Request Permissions : $\underline{\text { Click here }}$ 
XXV. Political Poems of the reigns of Henry VI. and Edward IV., communicated by Sir Frederic Maddin, K.H., in a Letter to John Gage Rokewode, Esq. Director S.A.

Read 10th March, 1842.

MY DEAR Sir,

British Museum, 7 March, 1842.

A SHORT time ago I took an opportunity of laying before the Society of Antiquaries by your hands, a Letter containing much interesting information on the state of parties in the year 1454; and I now beg leave to add, as a supplementary communication, copies of several Political Poems written at various periods of the reigns of Henry the Sixth and Edward the Fourth, all of which, with the exception of the first, have hitherto remained unpublished. Documents of this kind are confessedly not beneath the notice of the historian, since they shew the popular feelings of the time better than any other contemporary record, and often mention minute circumstances worthy of note, which may in vain be sought for elsewhere. In the Transactions of the Society some few specimens of this political versification have already appeared, of the reigns of Edward the Third, Richard the Second, and Edward the Fourth, ${ }^{a}$ and some others belonging to the reign of Henry the Sixth, may be found in the Excerpta Historica. ${ }^{\text {b }}$ Of

a Vol. XVIII. p. 22. Vol. XXI. p. 89. Vol. XXIX.p. 130.

b Pp. 159, 279, 360. There are also extant some verses, attributed to Lydgate, composed on the temporary reconciliation of the Yorkist and Lancastrian Lords, in March 1457-8, printed by Sir $\mathbf{H}$. Nicolas, at the end of the Chronicle of London, pp. 251, 254, 4to. Lond. 1827, from MSS. Cott. Nero A. vi. Vesp. B. xvi. 
the six poems now sent, five were composed by adherents of the house of York, the first of which relates to the murder of the Duke of Suffolk, in 1450 ; the second to the chiefs of the Yorkist faction, probably about May, 1460 ; the third to the battle of Northampton, in July following; the fourth, to the policy and position of the adverse parties, probably towards the end of the same year; and the fifth to the battle of Towton, in 1461. The remaining poem was written by a Lancastrian, and presents a curious contrast to the others. It enumerates the principal Lords on the King's side, and, under the metaphor of a ship, describes the position of each in the guidance and government of the state towards the close of the year 1458 .

Believe me, my dear Sir,

Yours very truly,

FREDERIC MADDEN.

To John Gage Rokewode, Esq.

F.R.S. Director S.A.

I.

SARCASTIC VERSES ON THE DEATH OF THE DUKE OF SUFFOLK, 1450 .

Tris poem has been printed by Ritson, in his Ancient Songs, p. 51, 8vo. 1790, but he has fallen into an extraordinary mistake respecting it; and having erroneously supposed its object to be "a Requiem to the Conspirators against Henry IV." in 1399, has ingeniously contrived to appropriate the greater part of the names mentioned in it to persons who were in their graves when the verses were actually composed! Had Warton been aware of the fact, it would have afforded him an excellent opportunity of retaliating on Ritson the censures so unsparingly bestowed by the latter on himself. It was again printed by Turner in the History of England, vol. iii. p. 74, ed. 8vo. 1830, but with many errors in the reading, and without any attempt at illustration. He speaks of it, however, rightly, as referring to the murder of the Duke of Suffolk and others of his adherents ; and remarks, that it is curious "for giving the names of those friends of the government who were nost hated by the people."

The date of this piece can be fixed with sufficient precision, since it must have been composed between the 2nd of May, the date of Suffolk's death, and the 29th June, the day on which the Bishop of Salisbury suffered a similar fate. The Latin sentences put into the mouths of the persons named, are taken from the usual Church Service for the

voL. $\mathrm{XX1X}$.

2 T 
Dead, but are, in some instances, incorrectly given both by Ritson and Turner. There is considerable humour shewn in the adaptation of the passages, and, no doubt, much of the satire is now lost to us, which must have been perceptible to a contemporary. The MS. from which it is taken is in the Cottonian collection, Vesp. B. xvi. fol. $1^{\text {b, }}$, written in a contemporary hand.

IN the monethe of Maij, when gresse growep grene, Flagrant ${ }^{a}$ in her floures, $w^{t}$ swete sauour,

Jac Napes b wolde ouer the see, a maryner to ben, With his cloge ${ }^{c}$ and his cheyn, to seke more tresour.

Suyche a payn prikkede hym, he asked a confessour :

Nicholas d said, "I am redi, thi confessour to be."

He was holden so, that he ne passede that hour;

For Jac Napes soule, Placebo and Dirige.

Who shalle execute his exequies, $\mathrm{w}^{\mathrm{t}}$ a solempnite?

Bisshopes and lordes, as grete reson is ;

Monkes, chanons, prestes, and other clergie,

Pray for this Dukes soule, pat it might come to blis.

And let neuer suyche another come after this :

His interfectours, blessed might thei be,

And graunte them for ther dede to regne $\mathrm{w}^{\mathrm{t}}$ angelis ;

And for Jac Nape soule, Placebo and Dirige.

Placebo begynnethe the bishop of Herforde, $\mathrm{e}$

Dilexi, for myn auauncement, saithe be bisshop of Chestre ; ${ }^{\text {f }}$

a Flagrant for fragrant, as we find flagrantia for fragrantia, in the Middle Age Latinity.

b A nickname for William De la Pole, Duke of Suffolk, who, after his fall, embarked from Ipswich with the intention of proceeding abroad, but was intercepted by some ships off Dover, and beheaded without ceremony by the shipmen, 2nd May, 1450. An interesting contemporary account of this transaction is given in the Paston Letters, vol. i. p. 38.

c A clog argent with a chain or, was the badge of Suffolk. See Excerpta Hist. p. 161.

d The name of the ship which intercepted the Duke was the Nicholas of the Tower.

e Richard Beauchamp, consecrated 9 Feb. 1448-9, and translated to Salisbury, 14 Aug. 1450

f William Booth, consecrated Bishop of Lichfield and Coventry (then usually called 
Heu me! saip Salisbury, ${ }^{\mathrm{g}}$ this gothe to ferre forthe, Ad Dominum cum tribularer, saip pe abbot of Gloucestre. ${ }^{\mathrm{h}}$

Dominus custodit, saip the abbot of Rouchestre, ${ }^{\mathrm{i}}$

Leuaui oculos, saip frere Stanbury, ${ }^{\mathrm{k}}$ volaui ; ${ }^{1}$

Si iniquitates, saip be bisshop of Worcetre ${ }^{\mathrm{m}}$

For Jac Nape soule, De profundis clamaui.

\section{Opera manuum tuarum, seip the Cardynal ${ }^{\mathrm{n}}$ wisely, That brought forthe Confitebor, for alle this Napes reson;}

Chester) $9 \mathrm{July}, \mathbf{1 4 4 7}$, and translated to York in 1452. In the Excerpta Historica, p. 357, are some curious satyrical verses addressed to him, as one of Suffolk's partisans. He is also named in the petition from the Commons, 29 April, 1451, among the persons whose removal was desired for "mysbehavyng." Rot. Parl. v. 216.

g William Aiscough, Clerk of the Council, consecrated $20 \mathrm{July}, 1438$. He was one of Suffolk's chief adherents, and murdered by his own parishioners under circumstances of great cruelty whilst saying mass, at Edindon, 29 June, 1450. See Godwin, p. 350. Stowe, p. 392.

h Reynold or Reginald Butler, who had the royal assent to his election, 29 Oct. 1437, and received the temporalities, the 12 Nov. following. He was promoted to the see of Hereford in Dec.1450, and translated to Lichfield, 3 April 1453. Whilst Abbot of Gloucester, he rendered himself so obnoxious as a partisan of Suffolk, that he was sent prisoner to Ludlow Castle by the Duke of York, and was included amongst those persons whom the Commons petitioned the King to remove, 29 Apr. 1451.

i William Wellys, Abbot of York, succeeded to be Prior of St. Andrew's, Rochester, in 1436. The period of his death is uncertain, but his successor died in 1467 .

k John Stanbury was Confessor to Henry VI. and the first Provost of Eton College, founded by that monarch. He was made Bishop of Bangor, $4 \mathrm{May}, 1448$, and translated to Hereford, 7 Feb, 1452-3. He was ever a staunch friend of Henry, and, at the battle of Northampton, induced the Lancastrian soldiers by his exhortations to make the greater resistance, for which he was taken prisoner, and confined a long time in Warwick Castle. He died in 1474. Godwin, p. 492.

1 There seems to be here some error, as there is no such word in the Service for the Dead. Perhaps we should substitute a repetition of the word levavi.

m John Carpenter, appointed by papal bull, 20 Dec. 1443. He resigned in 1476.

n John Kempe, Cardinal, and Archbishop of York, made Chancellor for the second time, 31 Jan. 1449-50. 
Audiui vocem, songe Allemightty God an hye, And perfore syng we, Magnificat anima mea Dominum.

Vnto this Dirige most we gon and come,

This pascalle tyme, ${ }^{\circ}$ to say reryli,

Thre psalmes and thre lessouns, $p^{t}$ alle is and somme :

For Jac Nape soule, Placebo and Dirige.

Executors of this office, Dirige for to synge,

Shalle begyn the bisshop of Synt Asse ; ${ }^{p}$

Verba mea auribus, saip abbot of Redynge, $q$

Alle your ioye and hope is come to alasse!

Conuertere, Domine, yet graunte vs grace,

Saip abbot of Synt Albans, ${ }^{r}$ ful sorily;

The abbot of pe Toure hille, ${ }^{s} w^{t}$ his fat face,

Quakep and tremulep, for Domine, ne in furore.

Maister Water Liard ${ }^{\mathrm{t}}$ shal syng Ne quando,

The abbot of Westmynstre, "Domine, Deus meus, in te speraui ;

Requiem eternam graunte them alle to come to,

perto a Pater noster, saip the bisshop of Synt Dauy. ${ }^{x}$

- Easter day in 1450 fell on 5th April. It was during the octaves that the Parliament was held at Leicester, in which Suffolk and his adherents were indicted for treason.

p Thomas - succeeded 27 Jan. 1449-50, and died about 1461.

q John Thorne, elected Abbot 7 Jan. 1445-6, and received the temporalities, 18 Jan. The period of his death is not known.

r John Stoke, previously prior of Wallingford, was elected Abbot of St. Alban's 28 Nov. 1440 , on the resignation of Whethamstede. He caused a monument to be erected to the memory of Humphrey, Duke of Gloucester, and died in 1451. See Monasticon, ii. 202.

$s$ This individual $I$ am unable to identify, owing to the want of a list of the Abbots of St. Mary de Graces, or Newminster, which is the monastery alluded to. In the reign of Henry VIII. a Victualling Office was erected on the site.

t Walter Liard or Lyhert, was Provost of Oriel College, Oxford, from which he was removed to the see of Norwich, $24 \mathrm{Jan} .1445-6$, and died 17 May 1472.

u Edmund Kyrton, who succeeded Abbot Harwedon between the 27 May and 20 Aug. 1440. He resigned 23 Oct. 1462, on account of his age and infirmities.

$x$ John De la Bere, consecrated 13 Nov. 1447. He is supposed to have died in 1460. Le Neve, p. 513. 
For thes soules, pat wise were and mightty, Suffolke, Moleyns, $\mathrm{y}$ and Roos, ${ }^{z}$ thes thre; And in especial for Jac Napes, pat euer was wyly; For his soule, Placebo and Dirige.

Rise vp, Say, a rede Parce mihi, Domine, Nichil enim sunt dies mei, pou shalt synge; pe bisshop of Carlyle ${ }^{b}$ [shal] synge Credo ful sore; To suyche fals traitours come foule endynge. The baron of Dudley ${ }^{c}$ with grete mornynge, Redethe, Tedet animam meam vite mee;

y Adam Moleyns, Keeper of the Privy Seal, and Bishop of Chichester, who succeeded to that see 3 Dec. 1445. From his being one of the members of the Suffolk administration, he was murdered by some shipmen at Portsmouth, 9 January, 1449-50. Suffolk, in his reply to the bill of impeachment against him, declared that the surrender of the French provinces of Mans and Anjou, was peculiarly attributable to Moleyns. This is sufficient to account for his unpopularity. In William of $\mathbf{W}$ yrcestre the detail of his death is given with more particulars than elsewhere. "Circa Epiphaniam Domini," he writes, Magister Adam Moleyns, Episcopus Cicestrensis, apud Portesmothe in hospitali ibidem [the Hospital of God's House, founded by Peter de Rupibus, Bishop of Winchester], portando ac solvendo soldariis aliisque nautis regios denarios, clamando eum proditorem regis et regni, unumque venditorum Normanniæ, miserabiliter interfectus est." Annales, p. 467, ap. Hearne, Lib. Nig. Scaccarii, 8vo. 1771 .

$z$ The person bere alluded to is, apparently, Sir Robert Roos, banneret, fourth son of William Lord Roos, of Hamlake. In Feb. 1442-3 he was associated with Suffolk, Moleyns, and others, to negotiate the peace between England and France, and the marriage between the King and Margaret of Anjou. He died 30 Dec. 1448. See a memoir of him in Sir HNicolas's Journal of Beckington's Embassy, 8vo. 1828, p. lxvii.

a James Fiennes, Lord Say, Lord Treasurer, killed by the rebels under Jack Cade, 4 July, 1450. As these verses appear to have been written before his death, they are singularly prophetic of his fate.

b Nicholas Close, appointed 14 March, 1449-50, and translated to Lichfield, 30 Aug.1452.

c John Sutton, Baron Dudley, summoned to Parliament from 15 Feb. 1440 to 15 Nov. 1482. He is included among those for whose dismissal from the King's person the Commons petitioned in 1451 . 
Who but Danyel d Qui Lasarum ${ }^{\text {e }}$ shal synge, For Jac Nape soule, Placebo and Dirige?

John Say ${ }^{f}$ redethe, Manus tue fecerunt me ; Libera me, syngethe Trevilian, ${ }^{\mathrm{g}}$ warre the rere!

That thei do no more so, Requiescant in pace;

Thus prayes alle Englond, ferre and nere.

Where is Somerset ? $^{\mathrm{h}}$ whi aperes he not here,

To synge Dies ire et miserie?

God graunte Englonde, alle in fere,

For thes traitours to synge Placebo and Dirige.

Meny mo per be behynde, pe sothe forto telle, $\mathrm{p}^{\mathrm{t}}$ shal messes oppon thes do synge;

I pray som man do rynge the belle, pat pese forsaiden may come to pe sacrynge. And pat in brief tyme, $w^{t}$ out more tarienge, pat pis messe may be ended in suyche degre; And pat alle Englond ioyfulle may synge, pe commendacion, with Placebo and Dirige.

d Thomas Danyel, Esquire of the King's body. See what has been said of him previously, p. 314.

e The commencement of the verse, Qui Lazarum resuscitasti a monumento fetidum.

f John Say was a member of the King's Council in 1454 and 1458. As one of Suffolk's partisans he had been named in the petition of the Commons, before referred to.

g John Trevilian, Esquire of the King's body. See a previous notice of him, p. 314.

h Edmund Beaufort, Duke of Somerset. At the time this poem was composed he was in France, as chief commander, and after the loss of Normandy, and the fall of Suffolk, was chosen as the principal adviser of the Crown. He came to England in November, 1450, and was killed in the first battle of St. Alban's, 22 May, 1455. 
Among the Cotton Rolls is one marked II. 23, containing various pieces in prose and verse, directed against the Lancastrians, as also several metrical prophecies, etc. collected by a zealous Yorkist, about the year 1451. Among them is a copy of the articles of impeachment exhibited by the Commons against the Duke in Feb. 1449-50, as printed in the Rolls of Parliament, v. 177, after which follow the annexed lines, evidently aimed against the same party :

For feer or for fauour of ony fals mañ,

Loose not, the loue of alle pe commynalte;

Be ware, and sey, by Seint Juliañ,

Duke, Jwge, Barone, Archebisshope, and he be,

He wolle repent it with in $\mathrm{p}^{\mathrm{s}}$ monthes thre.

Let folke accused excuse theym selff, and pey cañ,

Reseyue no good, let soche bribry be;

Support not theyme this wo by-gañ,

And take fro peym per wages and per fee,

And let theyme [weare ?] suche clothis as pey spañ,

Or by God and Seint Anne!

Som must go hens, hit may noñ othere weys be,

And els is lost alle $p^{\mathrm{s}}$ lond and we;

Hong vp suche meñ to oure souerayne lorde,

That euer counselde hym $w^{t}$ fals men to be acorde.

Anno Milleno Domini centum quaterno,

L. simplex pleno, caveat omnis homo.

In the same Roll occur the curious political and satyrical verses printed in the Excerpta Historica; and interspersed are the following historical scraps, relating to this period, and now first printed:

He is wise that is wode, he is riche pat hase no goode,

$\mathrm{He}$ is blynde pat may se, he is riche pat shalle neuer $\mathrm{i}$-the,

$\mathrm{He}$ is fledde bat is not ferde, and he abideth $\mathrm{p}^{\mathrm{t}}$ maketh alle your berde.

The Duke of Suffolke hathe marryede his nese, his suster dowghter, to pe Capdawe, etc. And yaf hym $w^{t}$ here pe revenewez pat come fro Bordeaux, that is to wete, vi.xx towne [tun] wyne yerly, $v^{c}$. li etc. in mony, pe whiche my lorde of Gloucestre hadde of yiffte of pe kynge, durynge his life, etc.

$\mathbf{M}^{d}$. the kynge is $\operatorname{xxvj}^{\mathrm{c}} \mathbf{M}^{1}$. ${ }^{1 \mathrm{i}}$ in $\operatorname{det}$, and he may dispende but xxxiiij Ml. of the whiche the kynge hathe no more in honde but $v M^{1}$. li and his expense commythe yerly xxxij $\mathbf{M}$.

At Tonnebrigge, fast by Sevenoke, per was Stafford slayne, pursday next before Myssomer. 
At Crayford [sic] myle fro Dertforde.

Primo die mensis Marcii anno r. r. Henrici Sexti $\mathrm{xxx}^{\circ}$ [1452], ther was my lorde of

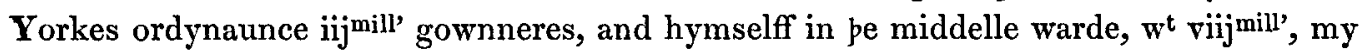

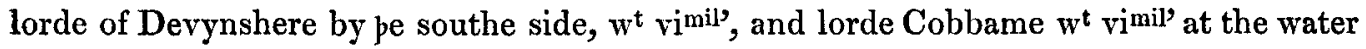
side, and vij shippers, $w^{t}$ jer stuffe. And sith pat tyme, and sithe, was poyntment made, and takene at Dertforde, by embassetours, my lorde pe B. of Wynchester, my lorde B. of Ely, my lorde pe Erle of Salusbury, my lorde of Warrewik, my lorde Bewchame, and my lorde of Sydeley, etc. whiche poyntment was, etc. And soone affter was Chatturley, yemañ of the Crowne, maymede, not withstondynge he was takyne at Derby $w^{t}$ money makynge, and ladde to Londone. Theñ affter, the kynges yemañ of his chambure, namyde Fazakerley, $w^{t}$ letteris was sent to Ludlow, to my lorde of Yorke, chargynge to do forthe a certeyne of his mayny, Artherñ, Squiere, Sharpe, Squiere, etc. the whiche Fazakerley hylde in avowtry Sharpus wiff, the whiche Sharpe slowe Fazacurly; and a bakere of Ludlow roos and pe commyns, etc.; the whiche bakere is at Kyllyngworthe castelle, etc. Affter pis my lorde of Shrousbury, etc. rode in to Kent, and set vp vi. peyre of galowes, and dede execucione vpone John Wylkyns, takene and broght to pe towne as for Capteyne, and $\mathrm{w}^{\mathrm{t}}$ othere mony mo, of the whiche xxviij. were hangede and be-hedede, the whiche hedes were sent to Londone, and Londone said per shulde no mo hedes be set vpone there; and pat tyme Etone was robbyde, and pe kynge beynge at Wynsore oñ Lowe Sonday, etc.

II.

VERSES ON THE STATE BY A LANCASTRIAN, 1458.

From MS. Trin. Coll. Dubl. E. 5. 10. a miscellaneous volume in prose and verse, compiled in the reigns of Henry VI. and Edward IV.; partly written on vellum, partly on paper, 4 to.

Fol. 30. De Navi vel Puppe, Anno Domini $\mathrm{M}^{1} \mathrm{cccc}^{\circ}$ lvijo ${ }^{\circ}$ litera dominical' g.

STERE welle the good shype, God be ouer gyde!

Ouer shyp is launched from the grounde,

Blessed be God, bothe faire and sounde ;

Ouer maryners han the shypmen founde,

aBy pere taklynge wille a-byde.

a Opposite to this line in the MS. is the following marginal note :-Nota, ut poeta satirus dat versus, fungar vice cotis, acutum reddere ferrum; in prologo Pollicronicon hoc. 
This noble shyp, made of good tree,

Ouer souerayne lord kynge Henry;

God gyde hym from aduersyte,

Where $p^{t}$ he go or ryde.

The shyp was charged $w^{\natural}$ a mast,

Crased it was, it my [ght] not last ; ${ }^{b}$

Now hathe he one $p^{t}$ wol not brest,

The old is leyde on syde.

Thys fayre mast, [th] is myghty yeard,

Of whom fals shrewes be a-fere[d],

Hys name of ryght is Prince Edward,

Long myght he $w^{t}$ vs a-byde !

The ship hathe closed hym a lyght, To kepe her course in way of ryght,

A fyre cressant, d f $^{t}$ bernethe bryg $\hbar t$,

$W^{t}$ fawte was neuer spyed.

Thys good lygit, $p^{t}$ is so clere,

Calle Y the Duke of Exceter, ${ }^{\mathrm{e}}$

Whos name yn troupe shyned clere,

Hys worshyp spryngethe wyde.

Thys shyp hathe a sterne fulle good,

Hem to gyde in ebbe and flood,

A-geyne per wawes bope wild and wode,

That rynnethe on euery syde.

The sterne that on pe shype is sette,

Ys pe Duke Somerset, ${ }^{f}$

b This may refer to the administration under Suffolk, which was dissolved in 1450 .

c Edward, only son of Henry VI. born 13 Oct. 1454.

d The Duke of Exeter is designated by the same badge in some verses in the Excerpta Hist. p. 161.

e Henry Holland, Duke of Exeter. See previously, p. 312.

f Henry Beaufort, son of the Duke who fell at St. Alban's. He was beheaded in May, 1464, after the battle of Hexham.

VoL. XXIX. 
For ragged rokkes he wolle not lette,

To sterre in ebbe and eke in tyde.

Ther is a sayle-yeard fulle good and sure,

To $p^{\mathrm{e}}$ shyp a grete tresour,

For alle stormes it wolle endure,

It is trusty atte nede.

Now pe sayle-yeard $\mathrm{Y}$ wolle reherse,

The Erle of Penbroke, ${ }^{\mathrm{g}}$ curtys and ferce.

A-cros $p^{\mathrm{e}}$ mast he hyethe travers,

The good shyp for to lede.

The mast hathe a welle good stay, $\mathrm{W}^{\mathrm{t}}$ shrowthes sure, Y dare wel say,

In humble wyse hym to obey,

Yf he to pem hathe nede.

The Duke of Bokyngham ${ }^{\mathrm{h}}$ thys stay is he :

Thys shrowdes be sure in thare degre.

Devenshyre, ${ }^{\mathrm{i}}$ and Grey, ${ }^{\mathrm{k}}$ and Becheham ${ }^{1}$ the free,

And Scales ${ }^{\mathrm{m}} \mathrm{w}^{\mathrm{t}}$ them in tyde.

The shyp hathe a welle good sayle,

Of fyne canvas, $b^{t}$ wolle not fayle,

$\mathrm{W}^{\mathrm{t}}$ bonet $^{\mathrm{n}}$ iii. for to travayle,

That mekelle beth of pryde.

g. Jasper Tudor, half-brother of Henry VI. created Earl of Pembroke in 1452.

h Humphrey Stafford, killed at the battle of Northampton, 1460.

i Thomas Courtenay, Earl of Devonshire, who succeeded his father, of the same name, in 1458. He stoutly adhered to Henry VI. and had a yearly sum of 100 marks granted him out of the forfeited estates of the Duke of York. He was beheaded by the Yorkists in 1461 .

k Edmund, Lord Grey of Ruthyn. He deserted at the battle of Northampton to tbe opposite party, and was created Earl of Kent by Edward IV. in 1465.

I John, Lord Beauchamp of Powyk, created in 1447. He was made Lord Treasurer, 22 June, 1450.

m 'Thomas, Lord Scales. Killed by the Yorkists in 1460, in attempting to escape from the Tower of London.

n In nautical language, a" bonnet" is an addition made to the lower part of a sail, in mo- 
This good sayle, Y vndurstond, The Erle of Northumb[er]land, ${ }^{\circ}$

Ros, ${ }^{p}$ Clyfford, ${ }^{\mathrm{q}}$ and Egremond, $\mathrm{r}$

The troupe is not to hyde.

Ther is a toppe, $p^{e}$ mast on hyght,

The shyp to defende, in alle hys ryght,

$W^{t}$ his foomen when he schalle fyg $\hbar t$,

They dare hym not a-byde.

The Erle of Schrovesbury ${ }^{s} b^{e}$ toppes name,

He kepethe pe shype from harme and blame,

The Erle of Wylchyre ${ }^{t}$ one of $p^{e}$ same

That kepethe pe shyp from drede.

Thys good shype hathe ankers thre,

Of bether mettel per may non be,

To strenthe $\mathrm{p}^{\mathrm{e}}$ shyp be londe and se,

When he wolle stop hys tyde.

The fu[r]st anker, hole and sounde,

$\mathrm{He}$ is named $\mathrm{p}^{\mathrm{e}}$ lord Beamond,

derate weather. In Capt. Nathaniel Butler's “Dialogicall discourse concerninge Marine Affaires, 1634," MS. Sloane, 758, p. 109, the word is thus explained: "The Bonnett is an addition onely of a piece of a sayle, made fitt to bee put unto another, soe that when seamen saye, that the shippe hath her course, and Bonnett abroade, theire meaninge is, that she hath the peice of sayle added unto her course, called the Bonnett, which before shee had not, nor ordinarily hathe."

- Henry Percy, who in the lifetime of his father was summoned to Parliament as Baron Poynings. He succeeded to the earldom in 1455, and was slain at the battle of Towton, 1461 .

p Thomas de Roos, Baron Roos of Hamlake. He was attainted in 1461.

q John, Lord Clifford, the murderer of the young Earl of Rutland at Wakefield. He was killed in 1461.

$r$ Thomas Percy, Earl of Egremont, created in 1449. He was killed in 1460, at Northampton.

s John Talbot, made Lord Treasurer in 1456, and killed also at Northampton, 1460.

$t$ James Butler, created in 1449, and held the office of Lord Treasurer twice, ir 1455 and 1458; beheaded in 1461 .

u John, Viscount Beaumond, created in 1440. Killed at Northampton, 1460. 
Wellys, ${ }^{x}$ and Ryveres, y troupe yn pem found, In worshyp pey hem gyde.

Now help Saynt George, oure Lady knyhћt, And be oure lode-sterre ${ }^{z}$ day and nyght, To strengthe oure Kynge, and England ryght, And felle oure fomenus pryde.

Now is oure shype dressed in hys kynde, $W^{t}$ hys taklynge be-for and be-hynde, Whos[o] loue it not, God make hym blynde!

In peynes to a-byde.

\section{III.}

\section{VERSES ON THE YORK1ST LORDS.}

From MS. Trin. Coll. Dubl. D.4, 18, the second portion of which consists of various pieces in prose and verse, chiefly written in the latter years of the reign of Henry VI. on paper, 4to. There is some difficulty in fixing the date of this poem, but in all probability it was in May, 1460, previous to the landing of the Earls of March, Salisbury, and Warwick, in Kent. Many other poems were doubtless composed about this time, and Stowe has preserved the commencement of "a long ballet made in favour of the Duke of Yorke and the sayde Erles," which was fastened on the gates of Canterbury at their arrival. It began thus :

"In the day of fast and spirituall affliction,

The celestiall influence of bodies transitorie."

Yerly be pe morowe, in a somer tyde, I sawe in a strete, in London as I went, A gentyl woman sittyng in Chepesyde, Syt wirkyng vpon a vestment.

$x$ Leo, Lord Welles, slain in 1461, at Towton.

y Richard Widville, created Baron Rivers in 1448, and father-in-law of Edward IV. by whom he was made Earl Rivers and Lord Treasurer. He was beheaded in 1469 by the peasantry.

z The MS. reads erroneously, lordes-sterre. 
She set $x i j$. letteris in order on a rowe, $b^{t}$ I might right wele vnderstande, porought pe grace of God it shal be knowe, pese xij. letters shal saue alle Inglande.

A litel while if pat ye wol dwelle, And yeue audience alle vnto me, What letters pei were, I shal you telle, pei were drawen out of pe a. b. c.

There was an $\mathrm{V}^{\text {a }}$ and thre arres to-gydre in a sute, $W^{t}$ letters oper, of whiche I shal reherse,

3. E. R. E. writen affter $b[\mathrm{e}]$ rute, M. S. R. and F. now haue I peyme expresse.

Styl as I stode, $\mathrm{w}^{\mathrm{t}}$ in a litel sesone, I construed pese letters pens or I went, And as I conseyued, be my semple resone, I shal telle you what bt woman ment.

The arris for thre Richard, $p^{t}$ be of noble fames, $\mathrm{p}^{\mathrm{t}}$ for pe rizt of Englond haue sufferd moche wo, York, Salesbury, and Warwik, pese be pe lordes names, pat alle Englond is be-holden to.

3 for 3 orke, $\mathrm{p}^{\mathrm{t}}$ is manly and myztfulle, $\mathrm{p}^{\mathrm{t}}$ be grace of God and gret reuelacion, Reynyng $w^{t}$ rules resonable and right fulle, pe which for oure sakes hape sufferd vexacion.'

$\mathrm{E}$ for Edward,c whos fame be erpe shal sprede, Be-cause of his wisdom named prudence, Shal saue alle Englond by his manly-hede, Wherfore we owe to do hym reuerence.

a So in the MS., but we should probably read " a W."

b Richard, Duke of York, was at this time in Ireland, to which he had been obliged to retreat after the failure at Ludlow in the October preceding.

c Edward, Earl of March, eldest son of the Duke of York; subsequently Edward IV. 
$M$ for Marche, trewe in euery tryalle, Drawen by discrecion pat worthy and wise is, Conseived in wedlok, and comyn of blode ryalle, Joynyng vnto vertu, excludyng alle vises.

$\mathbf{S}$ for Salesbury, ${ }^{\mathrm{d}} \mathrm{w}^{\mathrm{t}}$ out any questione, Rialle in his reynyng, and wise in euery case, He bryngethe many maters to goode conclusion, Called for his wisdom pater familias.

W for Warwik, ${ }^{e}$ goode $w^{t}$ sheld and oper defence, pe boldest vnder baner, in batelle to a-byde, For pe right of Englond he dope his diligence : Bope be londe and watyr God be his gyde!

$\mathrm{F}$ for be Feturlok, ${ }^{\mathrm{f}} \mathrm{p}^{\mathrm{t}}$ is of gret substaunce, pat hape mevid many maters porow his mediacion, In Englond and in Wales, in Scotlond, $\mathrm{s}$ and in Fraunce, He ridep and rulethe withe ryalle reputacion.

$\mathbf{R}$ for be Rose, ${ }^{\mathrm{h}} \mathrm{b}^{\mathrm{t}}$ fresshe is in euery stede, Bope pe rote and pe stalke ben gret of honoure, Fro Norway to Normandi beire power wol sprede, From Ryland ${ }^{i}$ to Estland men ioy of pat flowre.

d Richard Neville, Earl of Salisbury.

e Richard Neville, his son, Earl of Warwick. In the same MS. occurs this ftristich on his name, composed about the same period:

\section{Warwyk.}

W. wisdome monstrat, et adventus A. bene constat,

R. rightwisnes legi, W. willing prospera regi,

I. iust antiqui, K. kynd est, hic et ubique .

$f$ The badge of the Duke of York, and used on his seal in 1442 and 1445. See Sandford, p. 380, and Willement's Regal Heraldry, p. $\mathbf{5 4}$.

g Probably a mistake for Ireland. h Edward, Earl of March.

i Sic, perhaps for Ireland. 
E for pe Egle, ${ }^{k}$ bat gret worship hape wonne, porow spredyng of his wynges, $\mathrm{p}^{t}$ neuer dyd fle, per was neuer byrde, pat bred rndre sonne, More fortunat in felde ban $\mathrm{b}^{\mathrm{t}}$ birde hathe be.

$\mathbf{R}$ for pe Ragged Staf, ${ }^{1}{ }^{\mathrm{t}}$ noman may skapen, From Scotland to Cales pere of men stond in awe, In al Cristen landes is none so felle a wepen, To correcte soche caytiffes as do a-gayne be lawe.

Now haue I declarede pese xij. letters accordyng

To peire condicions, where pei ryde or gone, pouz pei be disseverid, pe olde from pe yinge, ${ }^{m}$ peire entent and purpos corden alle in oone.

That is, to destroy treson, and make a tryalle, Of hem $b^{t}$ be fauty, and hurten fulle sore, For pe wylle of Edward, ${ }^{\mathrm{n}}$ kyng most ryalle, That is pe moste purpos $\mathrm{b}^{\mathrm{t}}$ we labor fore.

k Richard, Earl of Salisbury. The allusion to his success in the field, must refer to the battles of St. Alban's and Blackheath, the latter of which was fought 23 Sept. 1459. He was beheaded after the disastrous battle of Wakefield, 30 Dec. 1460, which of course will fix the date of this poem anterior to that event.

1 The badge of the Earl of Warwick. When the Lords of the adverse factions came to London at the commencement of 1458 , for the purpose of reconciliation, Fabyan writes, " and the xiiijth day of February came the Erle of Warwyke from Calays, with a great bande of men, all arayed in rede iakettys, with whyte raggyd staues vpon them, and was lodgyd at the Grey Friars." p. 633.

$m$ This probably refers to the separation of the Yorkist lords, some of whom were in Ireland, and some at Calais. In the same manner writes Stowe, when speaking of their dispersion in 1457, "then were they separated in bodies, but in mindes and hearts knit together in one."

n There seems some mistake here in applying the title of king to Edward, whilst his father survived, since the whole tenor of the verses proves that York and Salisbury were both alive when the poem was written. I can only therefore suppose, that Edward is a mistake of the transcriber for Richard. 
Now pray we to pe prynce moste precious and pure, $\mathrm{p}^{\mathrm{t}}$ sytteth $\mathrm{w}^{\mathrm{t}}$ his seyntis in blys eternalle, Hur entent and purpos may last and endure, To the pleasaunce of God, and pe welfare of vs alle. Amen.

\section{IV.}

POEM ON THE BATTLE OF NORTHAMPTON, $10 \mathrm{JULY,} 1460$.

From MS. Trin. Coll. Dubl. D. 4, 18; a contemporary copy. The Yorkist Lords landed at Dover in June, 1460, and having been joined by the men of Kent, marched on to London, where they arrived $2 \mathrm{~d}$ July. Leaving the Earl of Salisbury, Lord Cobham, and Sir John Wenlock, to watch Lord Scales, who was in the Tower, Edward, with Warwick, Fauconberg, and Bourchier, advanced to meet the King. The rival armies met near Northampton, and on the 10th July the battle took place, in which, says Fabyan, "after long fighte, the Kinges hoost was sparbled [disparpled] and chasyd, and many of his noblemen slayne; among the which was the Duke of Buchyngham, the Erle of Shroysbury, the Vycount Beaumounde, the Lord Egremonde, with many other knyghtes and esquyers, and the Kyng taken in the felde." This poem must have been written before September, since it speaks of the Duke of York as absent in Ireland. The Duke landed in England about the 8th Sept. and came to London on the 10th October following.

OF alle mennys disposicion naturalle, Philisophyrs wryten in euery place, That affter the bodyes celestialle, The erthely body his wirkyn [g] hase;

Some tyme disposid it is to solace, Som tyme the contrary to hevynesse; And som tyme, by enspecialle grace, Sorow is turned into gladnesse.

And ${ }^{\text {a }}$ ensaumple here of I take witnesse, Of certeyne persones $b^{t}$ late exiled were,

a We should probably read $A n$. 
Whos sorow is turned into ioyfulnesse, pe Rose, ${ }^{\mathrm{b}}$ pe Fetyrlok, ${ }^{\mathrm{c}}$ pe Egle, ${ }^{\mathrm{d}}$ and pe Bere. ${ }^{\mathrm{e}}$

Grete games in Inglond sum tyme per were, In hauking, huntyng, and fisshing, in euery place, A-monge lordes $w^{t}$ shelde and spere, Prosperite in reme pan reignyng wase.

Where of God, of his specialle grace, Heryng be peple crying for mercye, Considering be falsehode in euery place, Gaue inflewenz of myrpe into bodyes on hye. The whiche in a Berwardf lighted preuelye, Edward, yong of age, disposed in solace; In hauking and huntyng to begynne meryly, To Northamptone $w^{t}$ pe Bere he toke his trace.

Now shal ye here a meruelous case, Allonly poroughe God oone prouysione; pe Berward and pe Bere pei did pe Dogges chace, And put peyme to flight, to gret confucione. pus a-gayne alle naturalle disposicione, To se a Bere to seke his owne game, But if it were of Goddis mocione, pat he shuld do pe Dogges shame.

Talbot ontrewe ${ }^{5}$ was pe oon Dogges name, Rauling Bewmond ${ }^{\mathrm{h}}$ anodre, I vnderstonde, pe thrid also was made ful tame, He was called bolde Egremonde. ${ }^{i}$
b Edward, Earl of March.
c Richard, Duke of York.
d Richard Neville, Earl of Salisbury.
e Richard Neville, Earl of Warwick.
$f$ Edward, Earl of March, so called from having the Earl of Warwick as his associate.
g John Talbot, Earl of Shrewsbury.
h John, Viscount Beaumond.
i Thomas Percy, Earl of Egremond. 
When pe Bereward come to pe grounde, Where he chased the forsaid leese, $k$ A-monge alle oper a Buk ${ }^{1}$ he founde, pe whiche was hye, and fat of greese.

pe coriages Berward put hym ferre in preese, To be Hunt, ${ }^{m}$ oure Kyng, he hyed hym ful fast ;

The Bere, for alle pe Dogges, wold not seese, But hyed hym sone afftre swyfftly in hast.

The Dogges barked at hem ful fast, pe Buk set $v p$ his hornes on hye, pe Berward, pei cryed, pei wold downe cast, The Bere also, if that he come nye.

The Bereward asked no questione why, But on pe Dogges he set fulle rounde; pe Bere made the Dogges to cry, And $w^{t}$ his pawme cast peyme to grounde. The game was done in a litel stounde, pe Buk was slayne, and borne a-way; A-gayne pe Bere pan was none hounde, But he might sporte, and take his play.

But pe Hunt he saued from harme $\mathrm{p}^{\mathrm{t}}$ day, He pouzt neuer oper in alle his mynde, He lowted downe, and at his fote lay, ${ }^{n}$ In token to hym that he was kynde. The Bereward also, pe Huntes frende, Felle downe on kne, saying $w^{t}$ obedience, "Souereigne lord, thenk vs not vnkynde, Nor take ye this in none offence.

k i.e. leash.

1 Humphrey Stafford, Duke of Buckingham.

m Huntsman; the King, Henry VI.

n Compare the account in Whethamstede, p. 482, and Stowe, p. 409. 
We haue desired to come to your presence, To oure excuse we myght not answere ;

Alle pinges were hyd from your audience, Where-fore we fled a-way for fere." The Hunt said bo, "I wol you here, Ye be right welcom bothe to me;

Alle way I pray you to stond me nere, Ye be my frendis, I may: wele se.

Stond vp, Berward, welcom be ye, Gramercy of you $[\mathbf{r}]$ gentyl game ; From you and your Bere I wol neuer fle, Tellipe me now, what is your name?" "Edward of Marche, I am pe same, Trewe to God and youre highnesse." pe gentyl Bere said, " $W^{t}$ outen blame We haue be put in gret hevynesse."

The Hunt answerid $\mathrm{w}^{\mathrm{t}}$ gret mekenesse, pe Dogges wrought a-gayne alle kynde; pei labored to bryng me in distresse, I was peire mayster and specialle frende. The Buk ran be-fore, pe Dogges be-hynde, I folowed affter; I wist neuer why; In no place game kowde I fynde, pe Buk and pe Dogges playde by and by.

A gentylle dogge wol naturally His mayster love, and drede also ; His kyndly game if he may a-spy, From hym belyre he wol be goo. These curre Dogges before dyd not so; pe Buk and-pey played par asent ; They lapped a-wey the fatte me fro, Me to myscheue was peire entent. 
And neuer to me pei wold consent, pe whiche called you euer treytours vntrewe;

Tyl now pe trewe comynerys of Kent

Be comyn $w^{t}$ you, falsehed to destrewe.

And trupe long exiled now to renewe;

Seynt Thomas I panke, in alle your right,

$\mathrm{p}^{\mathrm{t}}$ girded you pis day, and shewid to be trewe,

So fewe men slayne in so gret a fight.o

It was pe werk of God almight,

Of mannesse power it might not be ;

Gramercy, Faucon,p of pi fayre flight, pe bird from pe nest he made to fle."

To London now, pat fayre cyte,

pe Hunt was broughtq ful reuerently;

pe Berward, pe Bere, pe Fawcone fre,

Rode a-bouzt hym fulle ioyefully.

Thorow pat cyte rigћt opynly

pe Hunt rode, $w^{t}$ gret gladnesse;

pe pepil reioysed inwardly,

And panked God of his goodenesse ;

That he likep with lustynesse

To endewe pe Hunt, oure noble Kyng,

And to remeve his heuynesse,

Whiche to his regalle is no pyng conservyng.

The Egler from Londone was neuer remeving,

But hovid, and wayted vpon his pray;

-William of Wyrcestre, after giving the names of the noblemen slain, adds, "et alii ad numerum cce. personarum. Etiam submersi sunt in fugiendo plures." p. 481. But Hall states, that 10,000 persons were slain at this battle. $f$. clxxvi.

p William Neville, younger son of Ralph, Earl of Westmoreland. He married the heiress of Thomas, Lord Fauconberg, and was summoned to Parliament in her right, from 1429 to 1461. He was created Farl of Kent in 1461, and died in 1463.

$q$ The King reached London on the 16th July, and was lodged in the Bishop of London's palace. See Fabyan and Hall.

$r$ Richard Neville, Earl of Salisbury. 
Alle his delite was euer in fisshing, pe Fisshe ${ }^{\mathrm{s}}$ were closed in pyttes al way. Yit at pe last, vpon a day, pe Fisshe drewe nere vnto pe bayte; Nede hape no lawe, bus alle men say, pe Egle perto euer layde goode wayte.

To skape a-way it was ful strayte, pe Egyls birdes ${ }^{t}$ lay so peyme a-bowte; Euer beholding be falce dissayte, How from peyme alle pei wold gon oute. pe Egle lizted, and made hem to loute, pe Fisshe was feynte, and litelle of might; 3it iiij. there were, bope gret and stoute, pe whiche he toke alle at a flight.

Alle pei had scaped vpon a nyght, Saue peire Skales " were plucked a-way; pan had pe Fisshe lost alle here might, And litel ioy in watyr to play. Now God, $p^{t}$ madest bothe nyght and day, Bryng home pe mayster of pis game, pe Duke of Yorke, for hym we pray, $\mathrm{f}^{\mathrm{t}}$ noble prynce, Richard be name.

Whom treson ne falshod neuer dyd shame, But euer obedient to his souereigne; Falsehod euer more put hym in blame, And lay a-wayte hym to haue sleigne.

s Thomas, Lord Scales, together with Lords Vesci, Lovell, and Delaware, the Earl of Kendal, a Gascon, and others, had thrown themselves into the Tower, which they held against the Earl of Salisbury. See Stowe, p. 408.

$t$ The forces of the Earl of Salisbury.

u When the Tower was yielded, Lord Scales, with three others, endeavoured to escape, but was killed by some watermen of the Earl of Warwick, and his body left naked at the gate of " the Clynke." Hall. p. clxxvi. See also Will. Wyrcestre, p. 482, and Stowe, p. 409. 
If God be $w^{t} v s$, who is vs a-gayne?

He is so nowe, blessid mot he be ;

Of pis fortune alle men may be fayne,

$p^{t}$ right hape now his fre entree.

Blessid be God in Trinite,

Fadir and Son and Holy Goste,

Whiche kepithe his seruauntes in aduersite,

And wold not suffre peyme to be loste;

As pou art Lord of mightes moste,

Saue be Kyng and his ryalte,

And illumyn him $\mathrm{w}^{\mathrm{t}}$ pe Holy Goste,

His reme to set in perfyt charite. Amen.

\section{V. \\ POEM ON THE POSITION OF THE YORKISTS AND LANCASTRIANS, AND THE POLICY TO BE OBSERVED BY THE FORMER.}

From MS. Trin. Coll. Dubl. D. 4, 18; a contemporary copy. It is not easy to fix the date of these verses; but I am induced, after much consideration, to think they were written soon after the Duke of York had been recognised heir apparent to the throne, and Lord Protector, 19th Nov. 1460. The writer advises the heads of his party to be on their guard against the Lancastrians, and not to trust to an outward shew of amity. The allusion to the success of the Yorkists, and their being "set high on Fortune's wheel," can only well refer to the period above named, or to the winter of 1455 . Supposing the epithet of the Rose to refer to Richard, Duke of York, I would place the poem under the latter year; but, as this epithet is uniformly given to his son Edward Earl of March, I can hardly suppose that in 1455, when he had not attained his fifteenth year, he should be spoken of so prominently, as we find he is in the poem before us.

AWAKE, lordes, awake, and take goode hede, For som $\mathrm{p}^{\mathrm{t}}$ speke ful fayre, pei wolde your evil spede;

pouz pei pere in your presence $\mathrm{w}^{\mathrm{t}}$ a fayre face, And her tunge chaunged, pe hert is as it was. 
pei seyne in peire assemble, it is a wondre thyng, To se pe Rose ${ }^{a}$ in wyntre so fresshe for to spryng; And many barked atte Bere, ${ }^{b} b^{t}$ now be ful stylle, 3it pei wol hym wyrye, if pei might haue her wylle. But of your fewe fomen no thing pat ye drede, For be comyns ben youres, euer at youre nede ; zit a seege wold be set, pe falte to take and holde, For oon scabbed shepe, may enfecte al a folde. Trust not to moche in the fauour of youre foos, For pei be double in wirking, as pe worlde gos; Promysing feithfully obeisaunce to kepe, But perfite loue in peire hertis is leyde for to slepe, And pouz pei were pe Rose, or pe Ragged Staffe," pei rought neuer how sone, in feipe, $p^{t}$ ze starffe. For fyre and water to-gider in kyndeling [to] be brought, It passej mannes power, be God pat me bought ! Nor two fases in a hode ${ }^{d}$ is neuer to tryst, Bep wele war be-fore, and penk of had I wyst. ${ }^{\mathrm{e}}$ For pei hopen and tristen to here of a day, To se be Rose and pe Lione ${ }^{\mathrm{f}}$ brought to a bay; $\mathrm{W}^{\mathrm{t}}$ pe Egel $\mathrm{s}$ and pe Bere, $\mathrm{p}^{\mathrm{t}}$ worpi be in fight, From $p^{t}$ infortune preserue you God almight ! And lat not youre sauegardes be to liberalke, To your foos $p^{t}$ be turnyng euer as a balle ;

a Edward, Earl of March, whose cognisance of the white rose was derived from the castle of Clifford, and said to have been first used by Edmund of Langley, fifth son of Edward III.

b Richard Neville, Earl of Warwick.

c The badge of the Earl of Warwick.

d A proverb as early as the fourteenth century, and which has descended to our own time.

e A common proverbial expression in the fifteenth century. See MS. Harl. 5396, fol. $18 \mathrm{~b}, 19,21^{\mathrm{b}}$.

f John Mowbray, Duke of Norfolk, whose cognisance was a lion rampant, argent, for the barony of Segrave. See Excerpta Historica, p. 161, Collectanea Topographica, vol. iii. p. 66, and Retrospective Review, vol. ii. p. 515.

g Richard Neville, Earl of Salisbury, beheaded after the battle of Wakefield, 30 Dec. 1460. 
And sipe fortune hape set you hye on hir whele, And in youre comyns love, lovep ye hem as wele.

For many pat were pe Chayne ${ }^{\text {b }}$ on hir sleve.

Wole ful fayne youre lyves be-reve;

And som pat were pe Ragged Bottis, ${ }^{\text {h }}$

Had lever were pe Stafford Knottis ;

But what pei mene no man it wottes, perfore I counsel, eschewe peire lottis.

To telle you more it is no nede,

By counsel goode, zit take goode hede,

For a Cristmas gestenyng, as clerkis rede,

At on-set stevyn, ${ }^{k}$ is quyt in dede.

Wherfore I counsel you sempely as I can,

Of youre disposicion tellip not euery man;

Muche is in my mynde, no more is in my penne,

For pis shuld I be shent, might som men it kenne.

But pray we al to God $p^{t}$ died on a spere,

To saue pe Rose, pe Lyon, pe Egle, and pe Bere;

$\mathrm{W}^{\mathrm{t}}$ al oper lordes, trewe to youre assent,

Her sheld be euer God omnipotent.

Amen.

h Other allusions to the badges of the Earl of Warwick, the chained bear and the raggedstaff.

i The cognisance of the house of Stafford, the head of which was the Duke of Buckingham. See Excerpta Hist. p. 162.

$\mathrm{k}$ This proverb I recollect elsewhere, but cannot find the passage. Gestenyng means feast, as in Lazamon, vol. ii.p. 172, and in the romance of Kyng Alisaundre, vv. 1161, 1779. On-set stevyn is a phrase signifying a time not previously appointed, and is used by Chaucer, Cant. Tales, v. 1526, and in the ballad of Robin Hood and Guy of Gisborne, ap. Percy, vol. i. p. 87, ed. 1767 . 


\section{VI.}

VERSES ON THE BATTLE OF TOWTON, 29 MARCH, 1461.

From MS. Trin. Coll. Dubl. D. 4, 18. The fullest account handed down to us by historians of this conflict, is contained in the Fragment printed by Hearne at the end of Sprott's Chronicle, 8vo. 1719. p. 286, in which it is thus related:- "The viage determynid by the new elect King, Edward the iiiith. of the name, to folowe his ennemyes, King Harry the Sixte and his Queene, northward; first, on the morow [5th March], John, Duke of Norfolke, went in to his countrey with all diligence, to prepaire for the warre, on the party of King Edward. And on the Saturday next folowing, the Erle of Warwick, with a grete band of men, departid oute of London northwarde; where as on the Wednisday next folowing, the Kinges footemen [were assembled] in a grete numbre, of the which the moost parte were Wallshmen and Kentishmen. Then the Friday enswing, the King Edward isswid out of the cite in goodely ordre, at Busshoppisgate, then being the xiith day of Marche, and helde on his journayis, folowing thois othir; and when the fore prickers cam to Ferry-brigghe, theire was a grete skarmusshe, where as John Ratcliff, then Lorde Fitzwatir, was slayne; and theruppon they ever avaunced theime self til thay cam to Towton, viii. myles owte of Yorke, upon a Friday, at nizt, abyding the residw of theire company, the which were assemblid in goode ordre on the Satursday, then being Palmesondayis evin; and aboute iiii. of the clokke att nizt the ii. batailes joynid, and fauzt all nizt, till on the morow att aftir none, when aboute the noone, the forsaide John, Duke of Northfolke, with a fressh band of goode men of warre, cam in to the ayde of the new electe King E. This feelde was sore fouzten. For there were slayne on bothe partyes xxxiiiml. men, and all the season it snew. There were slayne therlis of Northumberland and Westmerland, with othir, and Sir Andrew Troloppe; and takin, therlis of Devinshire and Wiltshire, and behedid there. And the deposid King Harry, his Queene, with Harry, Duke of Somersett, and othir, in grete hast fledde in to Scotland."

These verses are rendered particularly curious by the enumeration given in them of the badges and banners displayed by the Yorkist Lords, and by the towns which sent troops to assist Edward the Fourth. From the scantiness of information, however, existing on this subject, it has not been found possible to illustrate these allusions so satisfactorily or fully as could have been wished.

Now is the Rose of Rone a growen to a gret honoure, Therfore syng we euerychone, I-blessid be that floure!

a Edward, Earl of March, was born at Rouen, 29 April, 1441.

vol. XXIX. 
I warne you euerychone, for [ye] shuld vnderstonde, There sprange a Rose in Rone, and sprad into Englonde;

He pat moued oure mone, poroughe pe grace of Goddes sonde,

That Rose stonte alone pe chef flour of this londe.

I-blessid be the tyme, that euer God sprad that floure !

Blessid be pt Rose ryalle, that is so fresshe of hewe, Almighty Jhesu blesse that soule, $b^{t}$ pe sede sewe, And blessid be pe gardeyne, per the Rose grewe; Cristes blessyng haue pei alle, $p^{t}$ to $b^{t}$ Rose be trewe ! And blessid be pe tyme, $b^{t}$ euer God sprad $b^{t}$ floure!

Be-twix Cristmas and Candelmas, a litel before be Lent, Alle pe lordes of je northe ${ }^{b}$ jei wrouzt by oon assent; For to stroy pe sowthe cuntre pei did alle hur entent, Had not the Rose of Rone be, al Englond had be shent. I-blessid be pe tyme, $p^{t}$ euer God sprad $p^{t}$ floure !

Upon a Shrof Tuesday, ${ }^{c}$ on a grene leede, ${ }^{\mathrm{d}}$

Be-twix Sandricche ${ }^{e}$ and Saynt Albons many man gan blede;

On an Aswedynsday we levid in mykel drede, Than cam je Rose of Rone downe, to halp vs at oure nede. Blessid be be tyme, pat euer God sprad b floure !

b These were, Northumberland, Westmoreland, Exeter, Somerset, Devonshire, Clifford, Roos, and Dacre.

c The second battle of St. Alban's, in which the Yorkists, under Warwick and Norfolk, were beaten, took place on Shrove Tuesday, 17 Feb. 1460-1.

d i. e. plain.

e Saundridge, two miles and a half from St. Alban's. Stowe writes, "At the north end of the towne, called Barnard heath, towarde a little towne called Syndridge, in a place called No mans lande, they [the Northern Lordes] hadde a far greater conflict, with fower or five thousand of the Kings armie, which gave the onset so fiercely at the beginning, that the victorie rested doubtfull a certaine time, till at the length, through the withdrawing many of the Kentish menne, with their Captaine, Lovelace, that was the vaward, King Henries part lost the fielde." p. 413. He adds, that 1916 persons were slain, of whom, Sir John Gray was the only man of note. 
The norpe $[\mathbf{r}] \mathrm{n}$ men made her bost, whan pei had done $\mathrm{j}^{\mathrm{t}}$ dede, "We wol dwelle in pe southe cuntrey, and take al $b^{t}$ we nede; These wifes and hur doughters, oure purpose shal pei spede,"Than seid pe Rose of Rone, "Nay, p $^{t}$ werk shal I for-bede." Blessid be the tyme, $b^{t}$ euer God sprad pat floure?

For to saue al Englond pe Rose did his entent, $\mathrm{W}^{\mathrm{t}}$ Calays and $\mathrm{w}^{\mathrm{t}}$ Londone, ${ }^{\mathrm{f}} \mathrm{w}^{\mathrm{t}}$ Essex and $\mathrm{w}^{\mathrm{t}}$ Kent ; And al pe southe of Englond, vnto pe watyr of Trent, And whan he saw pe tyme best, pe Rose from London went. Blessid be the tyme, ${ }^{t}$ euer God sprad pat floure:

The way into pe northe cuntre pe Rose ful fast he sought, $\mathrm{W}^{\mathrm{t}}$ hym went pe Ragged Staf, $\mathrm{g} \mathbf{p}^{\mathrm{t}}$ many man dere bought ;

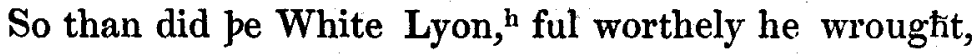
Almighti Jhesu blesse his soule, pt po armes ought! And blessid be pe tyme, $p^{t}$ euer God sprad pat floure!

The Fisshe Hoke ${ }^{i}$ cam into pe felde, $w^{t}$ ful egre mode, So did pe Cornysshe Chowghe, ${ }^{k}$ and broust forthe alle hir brode; per was the Blak Ragged Staf, ${ }^{l}{ }^{t} t$ is bope trewe and goode, pe Brideld Horse, pe Watyr Bouge ${ }^{m}$ by pe Horse stode. Blessid be the tyme, pat euer God spred that floure!

f lone londone, MS. And so again in the last stanza. g The Earl of Warwick.

h The Duke of Norfolk.

i Lord Fauconberg. So also in the satyrical verses in Excerpta Hist. p. 161, it is said of him, "The Fisshere hath lost his Hangulhooke."

k Probably John, Lord Scrope, of Bolton, whose cognisance was a Cornish chough. Retr. Rev. ii. 515. He was wounded in this battle. Paston Letters, vol. i. p. 218.

1 Edmund, Lord Grey of Ruthyn, afterwards Earl of Kent. See MS. Harl. 6156, f. 55. Retr. Rev. ii. 515.

m Probally Henry, Viscount Bouchier, afterwards Earl of Essex. 
The Grehound and pe Hertes Hede, ${ }^{\mathrm{n}}$ pei quyt hem wele $\mathrm{p}^{\mathrm{t}}$ day, So did pe Harow of Caunterbury, ${ }^{\circ}$ and Clynton ${ }^{p} w^{t}$ his Kay ; pe White Ship of Brystow, he feryd not $\mathrm{b}^{\mathrm{t}}$ fray, pe Blak Ram of Couentre, he said not one nay. Blessid be pe tyme $\mathrm{p}^{\mathrm{t}}$ euer God spred $\mathrm{p}^{\mathrm{t}}$ floure!

The Fawcon and pe Fetherlok $q$ was per that tyde, pe Blak Buller also hym self he wold not hyde; pe Dolfyn cam fro Walys, iij. Carpis be his syde, The prowde Libert of Salesbury, he gapid his gomes wide. Blessid be pe tyme, that euer God spred that floure!

The Wolf cam fro Worcetre, ful sore he poujt to byte, pe Dragon cam fro Glowcestre, he bent his tayle to smyte; The Griffon cam fro Leycestre, fleyng in as tyte, The George cam fro Notyngham, $\mathrm{w}^{\mathrm{t}}$ spere for to fyte. Blessid be pe tyme, that euer God spred pat floure!

The Boris Hede fro Wyndesover, $\mathrm{w}^{\mathrm{t}}$ tusses sharp and kene, be Estriche Feder ${ }^{\mathrm{s}}$ was in pe felde, $b^{t}$ many men myzt sene;

n Possibly meant for Thomas, Lord Stanley, afterwards Earl of Derby, although he is not mentioned by our historians, in their account of this battle. See " The most pleasant Song of Lady Bessy," edited by Tho. Heywood, 12 ${ }^{\circ}$. Lond. 1829, pp. 51, 65.

o This and most of the heraldic figures which are subsequently noticed, evidently refer to the banners of the towns which assisted Edward.

p John, Lord Clinton, is here alluded to, who joined the Yorkist party in 1459, for which his lands were seized, but subsequently restored by Edward IV. I do not understand the allusion to " his Kay." His badge was a mullet, nor does he appear ever to have been Lord Chamberlain.

$q$ One of the badges of the House of York. See Mr. J. G. Nichols's remarks in the Gent. Mag. Apr. 1842. p. 379.

r The Black Bull was used by Edward in reference to his descent from the House of Clare. In the Rolls of Parliament, express mention is made of this standard being carried at Towton by Ralph Vestynden, for which service he received an annuity of $£ 10$. Vol. vi. p.93.

$s$ The ostrich feather appears on the seals of Richard, Duke of York, and no doubt was 
The Wild Rat fro Norhamptone, $\mathrm{w}^{\mathrm{t}}$ hur brode nose, per was many a fayre pynone, wayting vpon pe Rose. Blessid be pe tyme, pat euer God spred that floure!

The norbe $[r] n$ party made hem strong $w^{t}$ spere and $w^{t}$ shelde, On Palmesonday, affter pe none, pei met vs in pe felde ${ }^{t}$ $\mathrm{W}^{\mathrm{t}}$ in an owre pei were right fayne to fle, and eke to yelde, xxvij. thousand ${ }^{u}$ be Rose kyld in pe felde. Blessid be be tyme, pat euer God spred $p^{t}$ Houre :

The Rose wan pe victorye, pe feld, and also be chace, Now may pe housband in the southe dwelle in his owne place; His wif and eke his faire doughtre, and al pe goode he has, Soche menys hap the Rose made, by vertu and by grace. Blessid be the tyme, pat euer God sprad that floure?

The Rose cam to London ${ }^{x}$ ful ryally rydyng, ij. erchebisshops of England pei crouned pe Rose kyng; Almighti Jhesu save pe Rose, and geue hym his blessyng, And al be reme of England ioy of his crownyng, $p^{t}$ we may blesse pe tyme, $p^{t}$ euer God sprad $p^{t}$ floure ! Amen, pur charite.

used as a royal badge or banner. See Willement's Heraldic Notices of Canterbury Cathedral, 4to. 1827. p. 48.

t In the Bill of Attainder afterwards passed against the Lancastrians, this battle is spoken of as having taken place " in a feld betwene the townes of Shirbourne in Elmett and Tadcastre, called Saxton feld and Towton feld." Rolls Parl. v. 477.

u The number of the slain is varionsly stated, as pointed out by Turner, vol. iii. p. 231. The number above best agrees with the statement given by a writer in the Paston Letters, vol. i. p. 220, where 28 thousand " nomberd by Harrolds" are said to have perished. No doubt this approaches nearest to the truth.

$x$ Edward made his triumphal entry into London on 26 June, 1461, and was crowned on Sunday, the 29th following, by the Archbishop of Canterbury, with great pomp. 